\title{
$\mathbf{V} \mathbf{M}$
}

VIA MEDICA

www.fr.viamedica.pl

'Katedra i Zakład Psychologii Klinicznej Uniwersytet Medyczny im. Karola Marcinkowskiego w Poznaniu

2Zakład Zarządzania w Ochronie Zdrowia Uniwersytet Medyczny im. Karola Marcinkowskiego w Poznaniu

${ }^{3}$ Katedra Reumatologii i Rehabilitacji Uniwersytet Medyczny im. Karola Marcinkowskiego w Poznaniu

\section{Wartość dla pacjenta - budowa strategii optymalizacji terapii chorób reumatycznych z perspektywy pacjenta, lekarza i firmy farmaceutycznej}

\section{Value for the patient - building a strategy for optimizing the therapy of rheumatic diseases from the perspective of the patient, doctor and pharmaceutical company}

\section{STRESZCZENIE}

Model opieki medycznej skoncentrowany na pacjencie stanowi jedno z podejść często uwzględnianych w badaniach naukowych. Celem pracy było przedstawienie ewolucji systemów opieki zdrowotnej w kierunku traktowania pacjenta jako najważniejszego i ostatecznego beneficjenta. Opisywany model wymaga pełnego obustronnego zaangażowania, otwartości w dyskusji oraz wspólnej, symultanicznej wymiany informacji. Taki sposób komunikacji poprawia zdrowie emocjonalne pacjenta, obniża poziom żalu przy niewłaściwej decyzji, pomaga utrzymać zalecany reżim leczenia, pozwala lepiej kontrolować ból i ma wpływ na ogólne wyniki leczenia. Zatem po- prawa zaangażowania chorego w proces leczenia wydaje się zasadnicza. Tutaj, istotną rolę odgrywają firmy farmaceutyczne podejmujące działania w obszarze społecznej odpowiedzialności biznesu (CSR) w zakresie edukacji, badań naukowych i profilaktyki. Aktywności pro-pacjenckie są także nakierowane na umacniania świadomości i zaangażowania chorego, pozytywnie wpływają na kształtowanie poczucia odpowiedzialności, motywacji i pozytywnego nastawienia. W artykule przedstawiono, jak działania CSR kształtują wartość dla pacjenta i wspierają całościowo proces zmagania się z chorobą.

Forum Reumatol. 2018, tom 4, nr 4: 231-237

Słowa kluczowe: choroby reumatyczne; społeczna odpowiedzialność biznesu; leczenie

\section{WSTEP}

Postęp w leczeniu chorób przewlekłych na przestrzeni ostatnich 20 lat przyniósł pacjentom znaczące korzyści. Zarówno rozwój terapii farmakologicznych, jak i ogólne zrozumienie mechanizmów powstawania i przebiegu chorób, pozwolił w znaczącym stopniu powstrzymać ich postęp, poprawiając jakość życia, a przede wszystkim wydłużając życie pacjentów [1]. Obecna opieka nad pacjentem, także w obszarze chorób reumatycznych, nie jest jedynie
Adres do korespondencji: Prof. dr hab. n. 0 zdrowiu Ewa Mojs Katedra i Zakład Psychologii Klinicznej

Uniwersytet Medyczny im. Karola Marcinkowskiego

w Poznaniu

e-mail: ewa_mojs@poczta.onet.pl 
farmakologicznym leczeniem objawowym, ale składową wiedzy z nabytych doświadczeń oraz najnowszych badań z zakresu nauk podstawowych i klinicznych z silną farmakologiczną ingerencją $\mathrm{w}$ mechanizmy patofizjologiczne choroby. Celem opieki w dzisiejszych czasach jest przede wszystkim osiągnięcie utrzymującej się remisji, pozwalającej na znaczną poprawę jakości życia pacjenta, utrzymanie jego sprawności fizycznej i psychicznej, a także obniżenie śmiertelności [2].

Doskonałym przykładem postępu w leczeniu pacjenta przewlekle chorego jest opieka nad pacjentem reumatycznym, a w szczególności leczenie reumatoidalnego zapalenia stawów (RZS). Reumatoidalne zapalenie stawów w znaczącym stopniu wpływa na pogorszenie jakości życia pacjentów i często prowadzi do inwalidztwa [3]. Postępowanie terapeutyczne leczenia RZS ewoluowało od zalecania niesteroidowych leków przeciwzapalnych (NLPZ) do powszechnego stosowania terapii skojarzonych syntetycznych leków modyfikujących postęp choroby (csDMARDs) z najnowszymi terapiami biologicznymi (bDMARDs). Takie leczenie, ze stosowanym metotreksatem (MTX), ma na celu szybką kontrolę i osiągnięcie remisji choroby $[4,5]$. Dalszy rozwój terapii biologicznych pozwolił na identyfikację wielu korzyści płynących z terapii synergicznych, gdzie najprawdopodobniej najważniejszym z obu perspektyw - pacjenta oraz lekarza - było długoterminowe zahamowanie stopniowej destrukcji strukturalnej stawów [6].

Leczenie klasycznymi lekami modyfikującymi przebieg choroby było zazwyczaj opóźnione do momentu ujawnienia się nieodwracalnych uszkodzeń stawów. W ostatnim dziesięcioleciu, etap wczesnej inicjacji leczenia biologicznego w tak zwanym oknie sposobności stał się obiektem zainteresowania badaczy [7]. W 2012 roku American College of Rheumatology [8] zaproponował, stosowanie agresywnej terapii wczesnego leczenia RZS na podstawie trzech najważniejszych aspektów:

1. wcześniejsze leczenie - lepszy rezultat;

2. konieczność zapobiegania nieodwracalnym zmianom strukturalnym stawów;

3. wczesna interwencja to największa szansa na utrzymanie sprawności fizycznej pacjenta, poprawę jego jakości życia oraz redukcję niezdolności do pracy z przyczyn choroby.

Dobrym przykładem jest analiza danych z północnoamerykańskiego rejestru CORRONA [9] przeprowadzona w 2011 roku. Badacze przedstawiają efekt wdrożenia leczenia bio- logicznego u pacjentów z wcześniej zdiagnozowanym RZS do chorych, u których terapię biologiczną rozpoczęto w bardziej zaawansowanych etapach choroby. W ciagu 5 lat od diagnozy 22,3\% pacjentów, którzy otrzymali nowoczesną terapię, osiągnęło remisję choroby. Dla porównania - ten sam cel terapeutyczny osiągnęło tylko $17,7 \%$ chorych leczonych lekiem biologicznym od 6 do 10 lat od diagnozy, a tylko $12,8 \%$, gdy terapię włączono po 11 latach od diagnozy.

W obecnym postępowaniu leczenia chorób reumatycznych bardzo istotną rolę odgrywają stawiane zarówno przez lekarza, jak i pacjenta cele terapeutyczne. Dzięki wprowadzeniu biologicznych terapii modyfikujących przebieg choroby, osiągnięcie stanu utrzymującej się remisji lub niskiej aktywności choroby stało się faktem i nie bez powodu znalazło odzwierciedlenie w stawianych punktach koncowych badań klinicznych [10] czy zalecanych celach rekomendacji towarzystw naukowych [11]. Teraźniejsze postępowanie w leczeniu chorób reumatycznych to tylko łagodzenie bólu, to holistyczne podejście skupiające na swej uwadze wszystkie aspekty choroby. Pacjent chce osiągnąć remisję, żyć bez bólu, być aktywnym, pracować zawodowo oraz podejmować decyzję wspólnie z lekarzem.

Obecnie jesteśmy świadkami ewolucji systemów opieki zdrowotnej w kierunku traktowania pacjenta jako najważniejszego i ostatecznego beneficjenta. Tutaj istotną rolę odgrywają firmy farmaceutyczne podejmujące działania w zakresie edukacji, badań naukowych i profilaktyki. Aktywności propacjenckie, nakierowane w celu umacniania jego świadomości i zaangażowania, pozytywnie wpływają na kształtowanie poczucia odpowiedzialności, motywacji i pozytywnego nastawienia $[12,13]$. Bardzo istotnym aspektem jest także poprawa dialogu na poziomie pacjent-lekarz [14], która w znaczącym stopniu pozwala na podniesienie poziomu świadomości pacjenta, wzrostu satysfakcji oraz ułatwia przestrzeganie ustalonych schematów dawkowania [15]. Historycznie częstym modelem podejmowania decyzji w relacji pacjent-lekarz był model paternalistyczny, w którym pacjent pasywnie zgadza się na zaproponowane przez lekarza opcje terapeutyczne [16]. Kolejny model relacji pacjent-lekarz, oparty na świadomej decyzji (informed decision-making model), w dużym stopniu promuje autonomię pacjenta. Lekarz przekazuje pacjentowi informację na temat dostępnych dla niego opcji leczenia i pozwala 
mu na podjęcie świadomej oraz samodzielnej decyzji. Rozważania i podejmowanie decyzji są jedynie przywilejami pacjenta, a lekarz ma być stroną przekazującą wymagane informacje i opcje terapeutyczne.

Najlepsze dla obu stron korzyści przynosi obecnie najbardziej promowany sposób interakcji — shared decision-making model. Wymaga on pełnego obustronnego zaangażowania, otwartości w dyskusji oraz wspólnej, symultanicznej wymiany informacji. Zauważono, że taki sposób komunikacji poprawia zdrowie emocjonalne pacjenta, obniża poziom żalu przy niewłaściwej decyzji, pomaga utrzymać zalecany reżim leczenia, daje poczucie odpowiedzialności i, chociażby w przypadku chorób reumatycznych, pozwala lepiej kontrolować ból i ma wpływ na ogólne wyniki leczenia [14, 16]. Model lekarza jako partnera-konsultanta w procesie leczenia odpowiada także postulatom takim jak:

- każdy uczestnik procesu leczenia ponosi określony poziom odpowiedzialności za przebieg i wynik leczenia;

- kontakty opierają się na obopólnej zgodzie;

- wola negocjowania istnieje po obu stronach relacji pacjent-lekarz;

- każda ze stron musi odnieść korzyść ze współpracy [16].

Obecnie działania zwiększające świadomość zdrowotną pacjentów, zarówno na poziomie globalnym (społecznym), jak i indywidualnym, podejmowane sa przez liczne instytucje zobowiązane do promowania zachowań prozdrowotnych. Uświadomienie pacjentom ich kluczowej roli w zakresie ochrony własnego zdrowia jest jednym z podstawowych zadań, a jednocześnie warunków powodzenia, wszelkich poczynań w zakresie promocji zdrowia [17]. Działania, które skierowane są na rzecz aktywności prozdrowotnych podejmowane są przez samorządy lokalne, władze administracyjne i organizacje pozarządowe, Ministerstwo Zdrowia, NFZ, a także część firm farmaceutycznych obecnych w Polsce, które oprócz celów komercyjnych, dążą przede wszystkim do budowania swojego wizerunku poprzez działania podejmowane na rzecz zdrowia społecznego, w których w centrum uwagi jest pacjent. Działania te wpisują się w strategie firm farmaceutycznych rozumiane jako społeczna odpowiedzialność biznesu (CSR, corporate social responsibility).

Społeczna odpowiedzialność biznesu nie jest w sposób jednoznaczny zdefiniowana zarówno w literaturze przedmiotu, jak i w dzia- łalności praktycznej. Istnieją różne opisy CSR, przy czym należy zwrócić uwagę, że interpretacja tej definicji zmienia się, dojrzewa na przestrzeni lat [19-24]. Tematyka CSR jest szeroko rozpowszechniana, ponieważ jedynie społecznie, odpowiedzialnie prowadzony biznes zwiększa konkurencyjność i wartość przedsiębiorstw w świecie biznesu, a zobowiązania wobec społeczeństwa, które są wpisane w strategie firm, powodują, że takie firmy będą zwracały uwagę zarówno na aspekty ekonomiczne, jak i społeczne. Społeczna odpowiedzialność biznesu jest wdrażana przez firmy dobrowolnie. Prowadzi do poprawy stosunków panujących z interesariuszami bądź samego makrootoczenia. W ujęciu Wayne'a Visser [25] wyróżnia się 5 etapów w rozwoju CSR przedsiębiorstw. Są to: era chciwości, filantropii, marketingu, zarządzania i era odpowiedzialności. Pierwszy etap to jedynie maksymalizacja zysku. Era filantropii, to zwrócenie się w stronę pozytywnego nastawienia do ludzi: działania charytatywne i inicjatywy społecznych. Era trzecia charakteryzuje się ważnością marki i reputacji, silnym powiązaniem działań CSR z PR. To etap promocji i budowania pozytywnego wizerunku wraz z wykorzystaniem CSR jako jednego z narzędzi działań marketingowych. Era zarządzania to strategiczne działania firm, związanych z realizacją zrównoważonego rozwoju. Czas odpowiedzialności to etap, w którym CSR opierany jest na nowych zasadach, przy zachowaniu dbałości o działania komunikacyjne i marketingowe, które przenoszone są do debat publicznych. Etap ten dotyczy problemów o wysokim znaczeniu dla społeczeństwa. Rozszerza się w kierunku partnerstwa z kluczowymi interesariuszami i obejmuje dobre praktyki na możliwie największą skalę. Ponieważ firmy farmaceutyczne, jako producenci leków, mają olbrzymi wpływ na zdrowie i życie ludzi, ich społeczna odpowiedzialność i wpływ, jaki wywierają na opiekę zdrowotną, jest bardzo wysoki. Zaangażowanie w działania społeczne w dużej mierze koncentruje się na tym, jak firma jest postrzegana przez społeczeństwo, ponieważ może to powodować budowanie zaufania wśród ludzi i kształtować pozytywny wizerunek na rynku lub też wywierać odmienny wpływ [26].

Zaangażowanie społeczne przedsiębiorstw jest ważnym instrumentem stosowanym w strategiach CSR i może być podzielone na cztery różne poziomy [27]. Poziom podstawowy obejmuje skutki, jakie firmy stwarzają dla wszystkich zaangażowanych stron, czyli 
produkcja, dostawa i dystrybucja produktów, sprzęt medyczny itp. Drugi poziom odnosi się do ich przedsięwzięć komercyjnych na poziomie społecznym - działania te mają na celu wspieranie rozwoju firmy, jej sukces komercyjny, na przykład poprzez promowanie wizerunku firmy. Kolejny poziom obejmuje inwestycje na rzecz społeczności lokalnej, które są długofalowymi działaniami podejmowanymi we współpracy z przedstawicielami społeczności, które firma chce wspierać [27]. Przykładami są dobrowolne działania firm [28, 29]. Czwartym, ostatnim z poziomów jest działalność filantropijna, czyli dotacje (w różnej postaci). Są one przeznaczane na rzecz dobra wspólnego w odpowiedzi na prośby i apele organizacji dobroczynnych, organizacji pozarządowych, osób indywidualnych. Czwarty poziom różni się od pozostałych, gdyż celami nie jest tu promocja wizerunku firmy. Są to działania wysoce transparentne [30, 31]. Działania CSR organizacji wpływają na naukę i szkolnictwo, sport i kulturę oraz ochronę zdrowia. Obserwując zmiany na rynku organizacji ochrony zdrowia, można zauważyć wiele działań CSR w otoczeniu zewnętrznym, szczególnie edukacyjnych, profilaktycznych, wspierania organizacji pacjentów z chorobami przewlekłymi, przeciwdziałających wykluczeniu chorych. Można zatem postawić tezę, że działania CSR podnoszą świadomość prozdrowotną oraz poziom zdrowia społeczeństwa.

Marketing społecznie zaangażowany to kolejne narzędzie wykorzystywane przez firmy do angażowania się w społeczności. Łączy w sobie cele promocyjne i potrzeby społeczne. Pozwala to firmom zwiększać zyski i jest strategią typu „win-win”. Istnieją również programy etyczne dla pracowników, społeczna odpowiedzialność w marketingu, standardy odpowiedzialnego biznesu, rynek inwestycji odpowiedzialnych społecznie, nadzór korporacyjny eko-znakowanie i znakowanie społeczne, zaangażowanie środowiskowe, a także kampanie społeczne, które mogą być skierowane na kulturę, sport, edukację dla pracowników służby zdrowia i ostatecznie pacjentów [27]. Tutaj na przestrzeni ostatnich 10 lat dominującą rolę odgrywają właśnie firmy farmaceutyczne, które w swojej działalności kierują się ideami CSR. Odgrywają szczególną rolę w działaniu na rzecz poprawy stanu zdrowia Polaków. Skupiają one swoje działania na edukacji zdrowotnej. W ostatnich latach na edukację zdrowotną firmy farmaceutyczne przeznaczyły $20 \mathrm{mln}$ PLN [26]. Do
2010 roku przeprowadzono ponad 60 kampanii edukacyjnych, z których skorzystało około 620 tys. osób [26]. Przykładem takich działań może być działalność firmy: TEVA Polska, która prowadziła wartą odnotowania kampanię „Tyle robi dla Ciebie, Zrób coś dla niej” [30]. Ta ogólnopolska kampania prowadzona pod patronatem Polskiego Towarzystwa Hepatologicznego miała na celu uświadomienie społeczeństwa w zakresie profilaktyki chorób wątroby. Kolejne warte odnotowania kampanie zostały podjęte przez Polpharmę, która w 2013 i 2014 roku przeprowadziła kilka szeroko zakrojonych kampanii edukacyjnych i profilaktycznych skierowanych do pacjentów, na przykład „Strefa na zdrowie” - program ułatwiający dostęp do badań lekarskich, konsultacji specjalistycznych i edukacji zdrowotnej dla osób w wieku 50+ [28]. Firma GlaxoSmithKline może pochwalić się licznymi kampaniami, które mają upowszechniać wiedzę na temat chorób nowotworowych i metod ich zapobiegania: „Piękna, bo zdrowa”, program „Mam Haka na Raka”, który jest realizowany we współpracy z Polską Unią Onkologii, a także inne znane mieszkańcom Polski, dotyczące zapalenia wątroby typu A/B oraz kampania profilaktyki szczepień przeciw rotawirusom: „Żółty tydzień,, „Powstrzymaj Rotawirusy”, „Positive Action” [29].

Dzięki kampaniom społecznym, firmy mogą szerzyć wiedzę wśród ludzi, odwołując się do określonego tematu i uświadamiać istotę i wagę problemu, chociażby określonej jednostki chorobowej. Przyglądając się aktywnościom firm farmaceutycznych w Polsce wspierających edukację prozdrowotną i wpływających na zwiększanie zaangażowania pacjentów reumatycznych w podejmowaniu decyzji terapeutycznych, należy wyróżnić działania, które od kilku lat można obserwować w Polsce (tab. 1).

\section{PODSUMOWANIE}

Można bez wątpienia stwierdzić, że obecna opieka zdrowotna nad pacjentami przewlekle chorymi ewoluowała i będzie nadal dynamicznie ewoluować. Choroby przewlekłe są jednymi z najbardziej wyniszczających chorób powodujących znaczne obciążenie pacjentów. Opisany powyżej przykład reumatoidalnego zapalenia stawów jest doskonałym przykładem na to, w jaki sposób postępy w nauce i zrozumienie niezaspokojonych potrzeb pacjentów, pomagają im i ich opiekunom zarządzać i tworzyć nowoczesne paradygmaty leczenia. 
Tabela 1. Przykładowe działania firm farmaceutycznych na rynku polskim, wspierające zaangażowanie pacjentów reumatycznych w podejmowanie decyzji terapeutycznych

\begin{tabular}{|c|c|c|c|}
\hline Firma & Program & Wartość dla pacjenta & $\begin{array}{l}\text { Poziom } \\
\text { zaangażowania }\end{array}$ \\
\hline ROCHE & RZS —porozmawiajmy & $\begin{array}{l}\text { Edukacja w zakresie komunikacji z lekarzem oraz } \\
\text { przestrzegania zaleceń terapeutycznych }\end{array}$ & $\begin{array}{l}\text { Kampanie } \\
\text { społeczne: } \\
\text { edukacja }\end{array}$ \\
\hline \multirow[t]{2}{*}{ ABBVIE } & Poruszyć świat & $\begin{array}{l}\text { Kampania wspierająca pacjentów w zakresie } \\
\text { informacji o chorobach: RZS, ZZSK, ŁZS, } \\
\text { możliwościach ich leczenia oraz informująca } \\
\text { o dostępie do opieki specjalistycznej }\end{array}$ & $\begin{array}{l}\text { Kampanie } \\
\text { społeczne: } \\
\text { edukacja }\end{array}$ \\
\hline & Dołącz do działania & $\begin{array}{l}\text { Służy ludziom na całym świecie jako źródło } \\
\text { informacji na temat RZS }\end{array}$ & $\begin{array}{l}\text { Kampanie } \\
\text { społeczne: } \\
\text { edukacja }\end{array}$ \\
\hline SANOFI & Świat w dłoniach & $\begin{array}{l}\text { Przełamanie bariery mówienia o chorobie, } \\
\text { edukacja w zakresie nowoczesnych metod leczenia } \\
\text { i rehabilitacji w RZS }\end{array}$ & $\begin{array}{l}\text { Kampanie } \\
\text { społeczne: } \\
\text { edukacja }\end{array}$ \\
\hline $\begin{array}{l}\text { ABBVIE, ROCHE, } \\
\text { UCB, GLAXO, } \\
\text { MEDAC, PFIZER, PTR, } \\
\text { "3majmy się razem" }\end{array}$ & $\begin{array}{l}\text { Reumatyzm ma młodą } \\
\text { twarz }\end{array}$ & $\begin{array}{l}\text { Zwiększenie świadomości społecznej na temat } \\
\text { chorób reumatycznych }\end{array}$ & $\begin{array}{l}\text { Kampanie } \\
\text { społeczne: } \\
\text { edukacja }\end{array}$ \\
\hline ABBVIE, PTR & $\begin{array}{l}\text { I BIEG "MOVE } \\
\text { IMPROVE - RUCH } \\
\text { USPRAWNIA" }\end{array}$ & $\begin{array}{l}\text { Uświadomienie społeczeństwu problemów } \\
\text { pacjentów cierpiących na RZS, ZZSK, MIZS, toczeń } \\
\text { rumieniowaty }\end{array}$ & $\begin{array}{l}\text { Kampanie } \\
\text { społeczne: } \\
\text { edukacja, sport }\end{array}$ \\
\hline UCB & $\begin{array}{l}\text { AKADEMIA } \\
\text { NOWOCZESNEJ } \\
\text { REUMATOLOGII }\end{array}$ & $\begin{array}{l}\text { Odpowiadanie na najczęściej zadawane przez } \\
\text { pacjenta pytania w zakresie choroby ZZSK }\end{array}$ & $\begin{array}{l}\text { Kampanie } \\
\text { społeczne: } \\
\text { edukacja }\end{array}$ \\
\hline
\end{tabular}

Źródło: opracowanie własne na podstawie dostępnych danych firmowych i z kampanii społecznych [30-38]

Odkrycie współczesnych immunoterapii biologicznych to znaczący kamień milowy, który wytyczył nową drogę w leczeniu chorób reumatycznych, dając nadzieję pacjentom na poprawę ich jakości życia. Leczenie przewlekłych chorób reumatycznych nie może jednak opierać się wyłącznie na terapeutykach. Pomyślne i pełne zaufania partnerstwo pacjenta z lekarzem jest kluczem, o którym mówi Gordon [39]. Lekarze powinni być zobowiązani do wzmocnienia swoich pacjentów i wspólnego podejmowania decyzji terapeutycznych. Pacjenci muszą jednak aktywnie angażować swoich lekarzy leczących i wykorzystywać dostępne środki edukacji, aby stać się bardziej świadomymi i niezależnymi.

Świadomość zdrowotna pacjentów wspierana jest obecnie nie tylko przez lekarza i farmaceutę. Informacje dotyczące aspektu życia w zdrowiu, profilaktyki i prewencji są powszechnie dostępne i szeroko rozpowszechniane w mediach. Pacjenci mają łatwy dostęp do informacji w zakresie samego aspektu choroby oraz życia $\mathrm{z}$ chorobą $\mathrm{w}$ jak najlepszej jakości. Dostępne są komunikaty, które poruszają aspekty konieczności wykonywania badań profilaktycznych, przestrzegania zaleceń lekarskich, prowadzenia zdrowego stylu życia, „bycia w formie” itd. Wszelkie działania nie są podejmowane w tym zakresie tylko przez lekarzy, pielęgniarki, czy farmaceutów w aptekach, ale w znaczącym stopniu przez samych pacjentów, zrzeszonych na przykład w stowarzyszeniach, oraz samych producentów leków, czyli firmy farmaceutyczne. Przedstawione powyżej wybrane przykłady działań w zakresie kampanii społecznych, które obejmują edukację pacjentów, ich rodzin, otoczenia, pokazują, jak bardzo ważną dla firm farmaceutycznych jest upowszechnianie wiedzy w zakresie profilaktyki i promocji zdrowia. Działania mogą wywierać wpływ na zmianę postaw i myślenia pacjentów zrzeszonych dookoła danej jednostki chorobowej. Pozwalają poszerzać wiedzę pacjentów w określonym temacie, uświadamiać wagę problemów i pokazywać możliwości radzenia sobie $\mathrm{z}$ nimi w codziennym życiu, w zgodzie $\mathrm{z}$ wybraną drogą leczenia. Dzięki temu pacjent ma coraz większą wiedzę, a to pozwala mu być dla lekarza partnerem w rozmowie dotyczącej jego choroby. Umożliwia zrozumienie wyboru sposobu leczenia, które obecnie jest wysoce zindywidualizowaną opcją, pozwalającą na jak najszybsze osiągnięcie przez pacjenta remisji 
choroby oraz daje możliwość realnego wpływu na podejmowane, w porozumieniu z lekarzem, decyzje terapeutyczne.

Warto dodać, że obserwowane w Polsce działania firm farmaceutycznych są częścią globalnych kampanii społecznych. Są one podejmowane w zakresie społecznej odpowiedzialności biznesu, która stała się jednym z podstawowych filarów działalności przedsiębiorstw farmaceutycznych. Dla nich pacjent staje się inspiracją i najistotniejszym źródłem informacji oraz głównym interesariuszem kierowanych aktywności na rynku.

\section{ABSTRACT}

Patient centricity has recently become an often direction for medical research, healthcare and corporate strategies. The aim of the study is to present current healthcare system transformation what brings patient in the center and creates solutions for persons with long term diseases. In novel approach to the treatment goals are common and mutually discussed by patients and physicians. Sustained disease remissions are now a fact and the quality of life of patients with chronic diseases improved significantly. Physicians and patients are becoming partners, discussing the best and personalized treatment decisions. Improvement of patient engagement is crucial. Patients are becoming more educated, informed and empowered. Patient centricity has always been an interest of Corporate Societal Responsibility (CSR) activities within pharmaceutical companies. CSR activities often aim at creating value for patients by health education, patient empowerment and improvement of patient-physician relationship. This review describes how advancements of the management of chronic diseases improves clinical outcomes, patient-physician relationships and patient empowerment. The article shows how CSR activities create value for patients and support the entire process coping with the disease.

Forum Reumatol. 2018, tom 4, nr 4: 231-237

Key words: rheumatic disease; Corporate Social Responsibility; treatment

\section{Piśmiennictwo}

1. Augustyn C, Walker B, Goss TF. Recognizing the Value of Innovation in the Treatment of Rheumatoid Arthritis. Boston Healthcare Associates, Inc., Boston, Washington, DC, Berlin, Shanghai, and Hong Kong, White papers 2013.

2. Upchurch KS, Kay J. Evolution of treatment for rheumatoid arthritis. Rheumatology. 2012; 51(suppl 6): vi28-vi36, doi: 10.1093/rheumatology/kes278.

3. Uhlig T, Moe RH, Kvien TK. The burden of disease in rheumatoid arthritis. Pharmacoeconomics. 2014; 32(9): 841-851, doi: 10.1007/s40273-014-0174-6, indexed in Pubmed: 24859304.

4. Rau R. Efficacy of methotrexate in comparison to biologics in rheumatoid arthritis. Clinical and Experimental Rheumatology 28. 2010; 5(Suppl. 61): S58-64.

5. Nixon R, Bansback N, Brennan A. The efficacy of inhibiting tumour necrosis factor alpha and interleukin 1 in patients with rheumatoid arthritis: a meta-analysis and adjusted indirect comparisons. Rheumatology (Oxford). 2007; 47(7): 1140-1147.

6. Heijde van der D, Breedveld FC, Kavanaugh A, et al. Disease Activity, Physical Function, and Radiographic Progression After Longterm Therapy with Adalimumab Plus Methotrexate: 5-Year Results of PREMIER. The Journal of Rheumatology. 2010; 37(11): 2237-2246, doi: 10.3899/jrheum.100208.

7. Singh JA, Furst DE, Bharat $A$, et al. 2012 update of the 2008 American College of Rheumatology recommendations for the use of disease-modifying antirheumatic drugs and biologic agents in the treatment of rheumatoid arthritis. Arthritis Care and Research (Hoboken). 2012; 64(5): 625-639.
8. Emery P, Breedveld F, Hall S, et al. Comparison of methotrexate monotherapy with a combination of methotrexate and etanercept in active, early, moderate to severe rheumatoid arthritis (COMET): a randomised, double-blind, parallel treatment trial. The Lancet. 2008; 372(9636): 375-382, doi: 10.1016/s0140-6736(08)61000-4.

9. Furst DE, Pangan AL, Harrold LR, et al. Greater likelihood of remission in rheumatoid arthritis patients treated earlier in disease course: Results from the CORRONA registry. Arthritis Care and Research (Hoboken). 2011; 63(6): 856-64.

10. Emery $P$, Bingham $\mathrm{CO}$, Burmester GR, et al. Certolizumab pegol in combination with dose-optimised methotrexate in DMARD-naïve patients with early, active rheumatoid arthritis with poor prognostic factors: 1-year results from C-EARLY, a randomised, double-blind, placebo-controlled phase III study. Ann Rheum Dis. 2017; 76(1): 96-104, doi: 10.1136/annrheumdis-2015-209057, indexed in Pubmed: 27165179.

11. Smolen JS, Breedveld FC, Burmester GR, et al. Treating rheumatoid arthritis to target: 2014 update of the recommendations of an international task force. Ann Rheum Dis. 2016; 75(1): 3-15, doi: 10.1136/annrheumdis-2015-207524, indexed in Pubmed: 25969430.

12. Dewulf L. Patient Engagement by Pharma-Why and How? A Framework for Compliant Patient Engagement. Ther Innov Regul Sci. 2015; 49(1): 9-16, doi: 10.1177/2168479014558884, indexed in Pubmed: 30222454 .

13. du Plessis D, Sake JK, Halling K, et al. Patient Centricity and Pharmaceutical Companies: Is ItFeasible? Ther Innov Regul Sci. 
2017; 51(4): 460-467, doi: 10.1177/2168479017696268, indexed in Pubmed: 30227057.

14. Smolen JS, Landewé R, Bijlsma J, et al. EULAR recommendations for the management of rheumatoid arthritis with synthetic and biological disease-modifying antirheumatic drugs: 2016 update. Annals of the Rheumatic Diseases. 2017, doi: 10.1136/annrheumdis-2016-210715.

15. Nota I, Drossaert HC, Vonkeman HE, et al. Patient participation in decisions about disease modifying anti-rheumatic drugs: a cross-sectional survey. BMC Musculoskeletal Disorders. 2014; 15: 333.

16. Mathews AL, Coleska A, Burns PB, et al. Evolution of Patient Decision-Making Regarding Medical Treatment of Rheumatoid Arthritis. Arthritis Care Res (Hoboken). 2016; 68(3): 318-324, doi: 10.1002/acr.22688, indexed in Pubmed: 26315611.

17. Sęk H, Heszen-Niejodek I. Psychologia zdrowia. Wydanie I. Wydawnictwo naukowe PWN, Warszawa 2012.

18. Stecko J. Zeszyty Naukowe Politechniki Rzeszowskiej nr 285. Zarządzanie i Marketing z. 19. 3/2012.

19. Hanke T, Stark W. Strategy Development: Conceptual Framework on Corporate Social Responsibility. Journal of Business Ethics. 2009; 85(S3): 507-516, doi: 10.1007/s10551-009-0215-9.

20. Bernatt M. Społeczna odpowiedzialność biznesu. Wymiar konstytucyjny i międzynarodowy. Wydawnictwo Naukowe Wydziału Zarządzania UW, Warszawa 2009: 23-27.

21. Jamali D, Mirshak R. Corporate Social Responsibility (CSR): Theory and Practice in a Developing Country Context. Journal of Business Ethics. 2006; 72(3): 243-262, doi: 10.1007/s10551-006-9168-4.

22. Visser W. Visser W. Wayne Visser, CSR 2. 0: The New Era of Corporate Sustainability and Responsibility. CSR International Inspiration Series No. 12008.

23. Rybak M. Społeczna odpowiedzialność biznesu - idee i rzeczywistość. Gospodarka narodowa. 2001(3): 23-47.
24. Marrewijk van M. Concepts and Definitions of CSR and Corporate Sustainability - between agency and communion. Journal of Business Ethics. 2003; 44(2): 95-105.

25. Visser W. The Age of Responsibility: CSR 2.0 and the New DNA of Business. Journal of Business Systems, Governance and Ethics. 2010; 5(3): 7, doi: 10.15209/jbsge. v5i3.185.

26. Makowska M. Koncepcja odpowiedzialności społecznej firm farmaceutycznych. Annales. Etyka w życiu gospodarczym. 2010; 13(2): 95-104.

27. Rok B. Odpowiedzialny biznes w nieodpowiedzialnym świecie. Akademia Rozwoju Filantropii w Polsce Forum Odpowiedzialnego Biznesu, Warszawa 2004: 34-52.

28. Raport Społecznej Odpowiedzialności Grupy Polpharma 2013-2014, 14-27. http://www.polpharma.pl/aktualnosci-firma/raport-spoleczny-grupy-polpharma/ (21.01.2018).

29. http://www.gsk.com.pl/odpowiedzialny-partner/darowizny-gsk. (21.01.2018).

30. http://www.teva.pl/About/Pages/Onas. (21.01.2018).

31. http://odpowiedzialnybiznes.pl/artykuly/filantropia-a-csr (12.12.2017).

32. Roche Polska i Roche Diagnostics Polska - zaangażowanie społeczne Raport 2016. https://www.roche.pl (21.01.2018)

33. http://poruszycswiat.pl/ (21.01.2018)

34. http://www.rzsdolaczdodzialania.pl/kampania-rzs-dolacz-do-dzialania.html (21.01.2018)

35. http://www.sanofi.pl///pl/pl/index.jsp (21.01.2018).

36. http://reumatyzmmamlodatwarz.pl/ (21.01.2018).

37. http://www.reumatologia.ptr.net.pl/?poruszyc-swiat,110 (21.01.2018).

38. https://www.ucb.pl/_up/ucb_pl/documents/Zesztywniajace\%20Zapalenie\%20Stawow\%20Kregoslupa_Poradnik\%20dla\%20Pacjentow.pdf (26.01.2018).

39. Gordon T, Sterling Edwards W. Pacjent jako Partner. Instytut Wydawniczy PAX, Warszawa 1999. 